\title{
Distributional patterns and possible origins of the tribes and genera of Coelidiinae (Homoptera, Membracoidea, Cicadellidae)
}

\author{
Mervin W. Nielson ${ }^{1}$ \\ William J. Knight ${ }^{2}$ \\ Yalin Zhang ${ }^{3}$
}

\begin{abstract}
Leafhoppers are well known biological indicators of zoogeographical regions owing, in part, to their phytodependency, high host plant specificity and relatively low vagility. In this connection, we discuss distributional patterns and possible zoogeographical origins of nine constituent tribes and their genera of the pantropical subfamily Coelidiinae. Among 118 known genera, only eight currently occupy more than one zoogeographical region, indicating an extremely high endemic profile which supports the proposed centers of origin and relatively low rate of intercontinental dispersal. The pantropical tribe Coelidiini is suggested as the basal group of the subfamily which is believed to have arisen prior to continental drift (late Jurassic-early Cretaceous) because there appears to be no other evidence at the present time to explain its near cosmopolitan distribution. Possible origins of three Old World tribes, Hikangiini (Ethiopian), Thagriini (Oriental) and Tharrini (Australian) and four New World -(Neotropical) tribes, Teruliini, Tinobregmini, Gabritini and Sandersellini are elucidated. The tribe Youngolidiini occupies the Neotropical and Ethiopian realms but its origin is problematical. There appears to be ample evidence that origin/dispersal patterns are related to the geological history of the areas occupied by its faunal members.

KEY WORDS. Homoptera, Membracoidea, Cicadellidae, Coelidiinae, distributional patterns
\end{abstract}

Leafhoppers are excellent biological indicators of zoogeographical regions (MetCalF 1949; LinnavUori 1959; Evans 1982; Nielson \& KNight 2000). Their phytodependency, high host plant specifity and relatively low vagility also contribute to their importance as ecological, altitudinal and insular indicators. The subfamily Coelidiinae, a moderately large pantropical group of leafhoppers, is exceeded in number of taxa only by the cosmopolitan subfamilies Deltocephalinae, Typhlocybinae and Cicadellinae among 40 or so recognized subfamilies. A discussion of the distributional profiles and possible origins of the remaining subfamilies and their constituent tribes are given in detail in a companion paper (NIELSON \& KNIGHT 2000).

1) Monte L. Bean Museum, Brigham Young University. Provo, UT 84604, USA.

2) The Natural History Museum. Cromwell Road, SW7 5BD, London, UK.

3) Northwestern Agricultural University. Yangling, China. 
In this paper, a review of the taxonomy, classification, biology and biogeography of the subfamily Coelidiinae is given. The zoogeographical distribution and possible origin of the constituent groups (genera and tribes) of the subfamily are presented in detail. The data are based on the presently known distribution of 118 genera ( 110 endemics) in nine tribes and the pathway of dispersal of eight genera that share bigeographical or multigeographical regions. No phylogenetic analyses are presented here. Therefore, inferences on zoogeographical origin are based on distributional analyses of the taxa and geological history of the occupied land areas as it is currently understood.

\section{Taxonomy and classification}

Acceleration of studies on the systematics of the subfamily Coelidiinae began over 30 years ago. Earlier investigations were largely descriptive in nature and they added numerous new taxa, many of which were assigned to the then taxonomically nebulous genus, Coelidia Germar, 1821a (CALDWELl \& MARTORELL 1952; DELONG 1945d,h, 1969a; DistANT 1908f,g, 1917a, 1918b, 1920a; EVANS 1941e, 1947a, 1966, 1971a; FABriCIUS 1803a; GERMAR 1821a; GiBSON 1917a; JACOBI 1905b, 1910b, 1912, 1914, 1944; KirBY 1894; KIRKALDY 1906c, 1907d; LAWSON 1932b; LINNAVUORI 1956a, 1960a,b; MATSUMURA 1914b; MELICHAR 1903b, 1905, 1926; METCALF 1954c; MONTROUZIER 1861; OSBORN 1911d, 1924c, 1934a,b; SCHUMACHER 1915a; SignORET 1853a, 1855d; SPANGBERG 1878b, 1879; Stål 1862e, 1864a, 1869a; VAN DUZEE 1907; WALKER 1851b, 1857b, 1858b,c, 1870b; WOLCOTT 1923b).

DOHRN (1859) was the first to propose the subfamily name and is, ipso facto, the author of the tribe Coelidiini, previously attributed to Evans by METCALF (1964). Distant (1908f) and BAKER (1915a) developed the basis for the tribe Thagriini. OMAN (1949) established Tinobregmini for the monobasic genus Tinobregmus Van Duzee, 1894f and DELong (1945d) proposed Sandersellini to accommodate the monobasic genus Sandersellus DeLong, 1945d. The tribal concepts of some of these groups were enlarged by EVANS (1947a), LinNAVUORI (1959b) and METCALF (1964b) by descriptive means and by adding additional genera and species. OMAN et al. (1990) updated a generic check-list and tribal assignment for the genera with distribution records.

Recent revisionary works of the subfamily covered nine tribes, including five new ones, Tharrini, Teruliini, Hikangiini, Youngolidiini and Gabritini, and their attendant genera and species (NIELSON 1975, 1977, 1979b, 1982e, 1983e). Many old species of Coelidia formed the basis for new genera and a number of old generic names were synonymized. The nominate genus was reduced from about 200 species to nine valid ones (NIELSON 1982e). Six additional new species have since been added to the type-genus (NIELSON 1983i, 1996b). Supplementary studies reinforced and further broadened the tribal concepts by adding new genera (NIELSON 1979a, 1982a, 1983h, 1986a, 1986b, 1988a, 1989a, 1991a, 1992a). New species augmented many of the former monobasic genera that previously had been described and the newly established genera complemented the heirarchical groups (NIELSON 1980a1996c; GODOY \& NIELSON 1998). The geographical range of the heirarchical groups 
was thus expanded and the diversity of the species and genera became more apparent. Other workers, KWON \& LEE (1979b); Li (1988, 1989, 1991, 1993); LI \& WANG (1989, 1991); ZHANG (1990, 1994); ZHANG \& AN (1994) and ZHANG \& ZHANG (1994), made significant contributions by adding new Oriental and Palaearctic species (primarily from China) which significantly extended the range of the genera Thagria Melichar, 1903b (Thagriini) and Taharana Nielson 1982e, Calodia Nielson, 1982e and Lodiana Nielson, 1982e (Coelidiini).

THERON (1986a) established the tribe Equeefini which he relegated to the subfamily Coelidiinae for a number of taxa that were more or less restricted to arid regions of southern Africa. These included a number of new taxa described by THERON (1984, 1986a, 1986b) and the genera Aletta Metcalf, 1952a, Equeefa Distant, 1910e, and Palicus Stål, 1866a that previously had been assigned to Coelidiinae by METCALF (1964b). These genera had been left standing for future assignment to a new but unproposed subfamily by NIELSON (1975). The assignment of the tribe Equeefini to the subfamily Coelidiinae by THERON (1986a) is not followed here. Therefore, the group is not included in this study. [Note: Palicus Stål, 1866a is preoccupied by Palicus Philippi, 1838 and considered a synonym of Aletta].

Nine tribes, 118 genera and 980 species are presently known in the subfamily (Tab. I). The majority of the genera are small and more than half of them are monobasic. The tribes Coelidiini and Teruliini each have about 50 genera. Sandersellini and Gabritini are each represented by a single genus, the Hikangiini and Thagriini by two genera, Tharrini by three and Youngolidiini and Tinobregmini by five each. Radiation has been extreme in Thagria (Thagriini, Oriental), Tharra Kirkaldy, 1906e (Tharrini, Australian) and Docalidia Nielson, 1979b (Teruliini, Neotropical), each genus represented by more than 100 species. The sum of these groups comprise about $1 / 3$ of the entire known fauna.

Table I. Biogeography of the taxa of nine tribes of Coelidiinae (Homoptera: Cicadellidae).

\begin{tabular}{|c|c|c|c|}
\hline Tribe & Number of genera & Number of species & Zoogeographical Realm \\
\hline Coelidiini & 51 & 343 & Pantropical 1 \\
\hline Gabritini & 1 & 4 & Neotropical \\
\hline Hikangiini & 2 & 6 & Ethiopian \\
\hline Teruliini & 49 & 283 & Near/Neot/Ethiopian 2 \\
\hline Thagriini & 2 & 184 & Orient/Austral 3 \\
\hline Tharrini & 3 & 105 & Orient/Austral \\
\hline Tinobregmini & 5 & 7 & Nearct/Neotropical \\
\hline Sandersellini & 1 & 9 & Neotropical \\
\hline Youngolidiini & 5 & 39 & Neotropical/Ethiopian \\
\hline Total & 118 & 980 & Pantropical \\
\hline
\end{tabular}

1) Not known in the Nearctic region or Australia proper; marginal in eastern Palaearctic region;

2) one adventitious species in West Africa; 3) marginal in eastern Palaearctic region.

\section{Biology}

Coelidiines are small $(3.10 \mathrm{~mm})$ to moderately large species $(11.00 \mathrm{~mm})$ that are readily recognized by their very large eyes which occupy from about half to over two-thirds of the entire dorsal area of the head. Host plant records of coelidiine species 
are poorly known. The degree of host specificity is known for only a few of these species for which host records are available. However, it is believed that most coelidiine specimens have been taken on shrubs and/or trees. The Nearctic members of the tribe Tinobregmini prefer mixed grass/herbaceous dicot communities.

Population densities of coelidiine species are generally very low in their tropical habitats, a peculiarity not exhibited in Central America by other groups of leafhoppers such as Cicadellinae, Deltocephalinae and Typhlocybinae. However, high populations of males of Lodia parapectinata Nielson, 1988 were taken in Malaise traps in the rain forest (NIELSON 1988a), and in more temperate regions populations of Tinobregmus vittatus Van Duzee, 1894, Harasupia snowi (Lawson, 1927) and Jikradia olitoria (Say, 1830) are sometimes quite abundant and have been collected by the senior author.

The atypical large eyes, a major character of the subfamily, may be indicative of nocturnal activities. Evidence of such activity was observed by the senior author in Costa Rica where coelidiines composed $90 \%$ of the leafhopper species in pan traps that were exposed for 12-hour overnight periods.

\section{Biogeography}

The zoogeographical regions and subregions as formulated by WALLACE (1876) are followed here with some refined modifications proposed by GoOD (1974) where plant communities played an important role in promoting or limiting the distribution of the taxa. It is well known that leafhoppers are excellent biogeographical indicators. This is the premise on which we have based our studies. Our interpretation of endemicity, dispersal pathways, and origin are related to the evidence presented herein which may be contrary to those views proposed by other workers.

Fossil records indicate abundance (ancestral forms) from lower Permian to Jurassic times (EVANS 1982) and the earliest leafhoppers ancestral to extant cicadellids have been reported from the Jurassic period in Kazakhastan (SHCHERBAKOV 1992). We emphasize that the current zoogeographical occupations from a very narrow restricted zone to very broad continental regions do not necessarily reflect past occupations which may have been more or less extensive than at present. Further, it is possible that many of the presently restricted taxa are the surviving remnants of once widely distributed forms.

Coelidiines are prevalent chiefly in the tropical regions (pantropical) of the world (Fig. 1). Only a few species have dispersed into the Nearctic and Palaearctic regions and these are restricted primarily to the southeastern and eastern zones, respectively. Ecological restraints appear to have limited the subfamily from occupying the hot, dry (southern and northern Africa, Australia) to the cool, dry to moist (Chile, Argentina, Nearctic, Palaearctic) habitats.

The biogeographical distribution of nine tribes vary from near cosmopolitan (Coelidiini) to endemics in the Ethiopian (Hikangiini) and Neotropical (Gabritini, Sandersellini) regions. Four tribes (Thagriini, Tharrini, Tinobregmini, Youngolidiini) occupy no more than two biogeographical realms (see below). The Teruliini are present in the Neotropical, Nearctic and Ethiopian regions, the latter having a single

Revta bras. Zool. 17 (4): 915 - 940, 2000 




Fig. 1. Distribution of the subfamily Coelidiinae.

representative, Biadorus africanus (Spangberg, 1878), which appears to be adventitious. The tribe Youngolidiini occupies the Neotropical and Ethiopian regions but the group is believed to be composed of two tribal elements, occupying respective geographical regions, pending phylogenetic analysis. The Tinobregmini are marginally represented (Mexico and southern United States) in the Neotropical and Nearctic regions. Thagriini are primarily Oriental and Tharrini are chiefly Australian although both of these unique groups overlap the Wallacean boundary between the Oriental and Australian realms.

The majority of the known coelidiine genera are endemic to their respective zoogeographical region. Most of the endemic genera occupy the Neotropical region (77) whereas the remainder are in the Ethiopian (15), Oriental (6), Australian (3) and Nearctic (1) regions (see tables under respective tribes).

Genera occupying more than one zoogeographical region are shown in table II. Only eight genera in the subfamily have bigeographical or multigeographical distributions. The possible origin and pathway of dispersal of these genera are discussed under the treatment of their attendant tribes.

Table II. Shared genera of the subfamily Coelidiinae in seven interzoogeographical regions.

\begin{tabular}{lll}
\hline \multicolumn{1}{c}{ Interzoogeographical Region } & \multicolumn{1}{c}{ Genus } & Tribe \\
\hline Palaearctic/Oriental & Lodiana & Coelidiini \\
Palaearctic/Oriental/Ethiopian & Calodia & Coelidiini \\
Oriental/Ethiopian & Mahellus & Coelidiini \\
Oriental/Australia/Palaearctic & Thagria & Thagriini \\
Neotropical/Nearctic & Harasupia, Jikradia & Teruliini \\
Neotropical/Ethiopian & Biadorus & Teruliini \\
Australian/Oriental & Tharra & Tharrini \\
\hline
\end{tabular}




\section{Treatment of the tribes}

\section{Coelidiini Dohrn, 1859}

The tribe is pantropical, ranging from the Neotropical region through tropical Africa to near the middle of the Austro-Malayan subregion (Irian) (Fig. 2). A few species have dispersed into the eastern Palaearctic region. Poor representation of this group in the Australian region (absent from Australia proper) is believed to be related to late geological development of the area and the early isolation of continental Australia (BRIGGS 1989). The Austro-Malayan area arose during the Cretaceous (BROWN \& GIBSON 1983) after radiation of the group on the mainland of the Oriental region was believed to be well underway. Australia was apparently too far isolated at the time to receive elements of the Oriental coelidiine fauna through the Indo-Malayan land bridge.

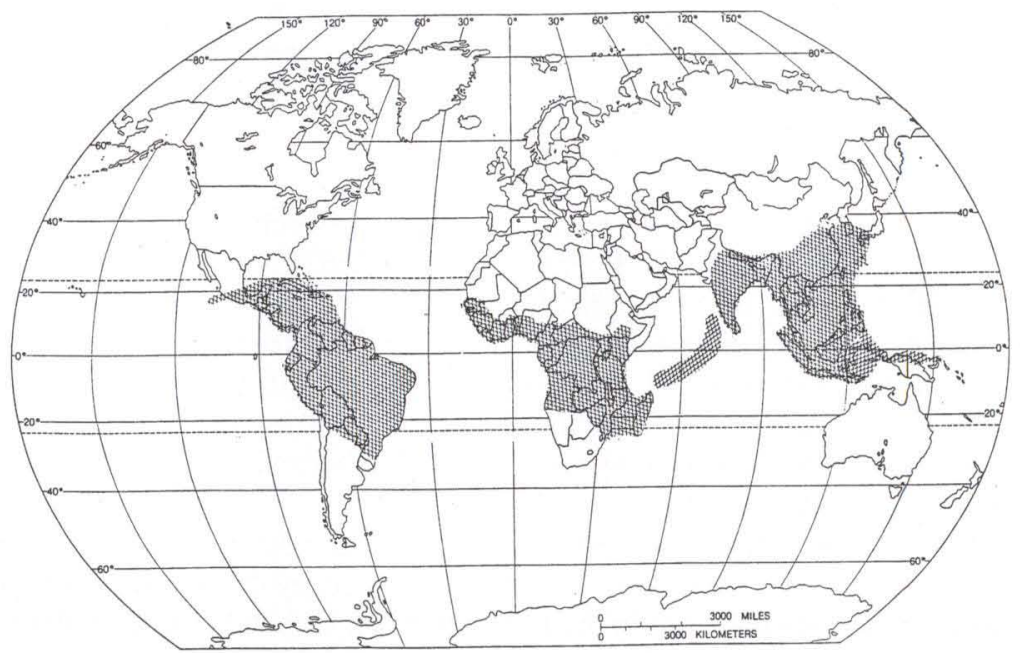

Fig. 2. Distribution of the tribe Coelidiini.

No endemic genera of this group are known in the Australian or Palaearctic regions and there are no representatives at all in the Nearctic region. Only a few species are endemic in the Palaearctic region and they appear to be derived from three (Calodia, Lodiana, Taharana) Oriental endemic genera (NIELSON 1990b, 1996b).

The tribe has the largest number of known genera and species (Tab. I). The Neotropical region is richest in genera (30), followed by the Ethiopian region (15) and the Oriental region (6), but the latter region has the richest fauna in number of species. Species richness averaged two per genus in the Neotropical region, five in the Ethiopian region and 27 in the Oriental region. The higher number of species groups (genera) in the Neotropical region may be related to plant diversity and ecological niches (refugia) that are prevalent in that area (BROWN \& GIBSON 1983). 
Relatively low species richness (per genus) in the region might possibly be related to a higher probability of extinction that is particularly evident with small, isolated populations (MACARTHUR \& WILSON 1967). If this scenario is true, then the extinction of much of the Neotropical fauna may be well underway.

The genera of the tribe in the Oriental and Australian regions are phenetically closer to each other than they are to the Ethiopian and Neotropical genera (NIELSON 1982e). They have closer affinities to the Ethiopian fauna than to the Neotropical group. The Ethiopian fauna likewise have closer affinities to the Oriental fauna than to the Neotropical group. These relationships are similarly borne out among other subfamilies of leafhoppers and their attendant tribes and genera (NIELSON \& KNIGHT 2000). The taxal affinities also appear to be correlated to geographical distance, i.e., the closest adjacent regions have the closest faunal relationships and the most distant geographical areas have the most distant taxal relationships (NIELSON 1982e). Numerous examples of similar biotic/geographical relationships have been referenced by BROWN \& GIBSON (1983), particularly the flora between Africa and South America (THORNE 1973).

The desertification of the region between the Afrotropical and Oriental realms (a vicariant event) may have separated a formerly contiguous coelidiine fauna when the entire area was once tropical, such that each group retained related but distinctly different taxal properties (NIELSON \& KNIGHT 2000). Another possibility is the transport of fauna via the Indian subcontinent when it drifted to southern Asia from its earlier association with the African element of Gondwanaland. Many examples of other biota (including fossils) in India have connections to Africa (BRIGGS 1989), which appears to support the close Ethiopian/Oriental tie for this group of leafhoppers.

Insular occupations of the tribe include Socorro Island (Mexican subregion), the West Indies (Caribbean subregion), Madagascar and the Seychelles (Malagasian subregion), the Maldives and Laccadives (Indian subregion), Sri Lanka (Sri Lankan subregion), the numerous islands of the Indo-Malayan and Austro-Malayan subregions and the Bonin islands off southern Japan (Manchurian subregion). Leafhopper occupations of insular areas are believed to have occurred by dispersal but the West Indies represent at least one exception in which island endemism was the result of plate tectonics (see Kramerolidia Nielson, 1982e below). The distribution of the genera and species of the tribe Coelidiini in five zoogeographical regions is shown in table III. Subregions for each region are included where the fauna are known either by endemics or dispersal from other subregions or regions. In the Neotropical region, the Brazilian subregion has the richest fauna which may possibly be the center of origin for the New World elements of the tribe. Few genera and species occupy the far northern (Antillean) and northwestern (Mexican) subregions and no dispersals have occurred into the Nearctic region. Over half (17) of the Neotropical genera of Coelidiini are currently monobasic. Among the known genera, only two presently have more than 10 species. Coelidia, the largest genus, is represented by 14 known species.

Several genera have rather discrete distributions, e.g., Kramerolidia, Omanolidia Nielson, 1982e and Boliviela DeLong, 1969. Kramerolidia is endemic to the Antillean subregion (West Indies) whereas Omanolidia ranges from Colombia through the southern Mexican subregion with one insular species on Socorro Island

Revta bras. Zool. 17 (4): $915-940,2000$ 
off the west coast of Mexico (Fig. 3). Boliviela is currently restricted to northwestern South America (Bolivia, Colombia, Ecuador, Peru) and likely originated in that region. Most of the species occur in Bolivia and Peru. It has yet to cross the Panamanian isthmus (Fig. 8). The lack of known species of Kramerolidia in South America (including Trinidad) and Central America suggests that this group had its origin during the Cretaceous period in Central America when the two American continents were joined. The continents separated during the Turonian (90 m.y.a.) and Central America (Caribbean plate) drifted northeastwardly to form the West Indies (CONEY 1982), thus isolating the genus which has since radiated to seven known species. The continents rejoined via the Cocos plate about 80 million years later during the Miocene (6 m.y.a.) (KELlogG \& VEGA 1995). Several genera of other leafhopper subfamilies (e.g. Cicadellinae, Agalliinae) were similarly isolated (NIELSON \& KNIGHT 2000) and each has radiated, which appears to avoid the need for long distance dispersal as proposed by DarLingTON (1938). When the land bridge (Cocos plate) rejoined the continents, Omanolidia appears to have radiated between the Mexican subregion and Colombia (Fig. 3). The exact origin and direction of radiation/dispersal of this group is problematical, although $90 \%$ of the species presently occur in Mexico.

Table III. Distribution of the fauna of the tribe Coelidiini in five zoogeographical regions.

\begin{tabular}{|c|c|c|}
\hline Realm and subregion & Number of genera & Number of species \\
\hline \multicolumn{3}{|l|}{ Neotropical } \\
\hline Mexican & 4 & 15 \\
\hline Brazilian & 22 & 72 \\
\hline Antillean & 1 & 7 \\
\hline Brazilian/Mexican & 3 & 4 \\
\hline Subtotal & 30 & 98 \\
\hline \multicolumn{3}{|l|}{ Oriental } \\
\hline Indo-Chinese & 3 & 90 \\
\hline Indo-Malayan & 2 & 44 \\
\hline Indian & $0^{*}$ & 22 \\
\hline Indo-Malagasian & 1 & 1 \\
\hline Subotal & 6 & 157 \\
\hline \multicolumn{3}{|l|}{ Ethiopian } \\
\hline West/East African & 7 & 57 \\
\hline West African & 5 & 7 \\
\hline East African & 2 & 2 \\
\hline Malagasian & 1 & 5 \\
\hline Subotal & 15 & 71 \\
\hline \multicolumn{3}{|l|}{ Australian/Oriental } \\
\hline Austro-Malayan & $0^{*}$ & 1 \\
\hline \multicolumn{3}{|l|}{ Oriental/Palaearctic } \\
\hline Manchurian/Siberian & $0^{*}$ & 7 \\
\hline Subotal & 0 & 8 \\
\hline Total & 51 & 334 \\
\hline
\end{tabular}

$\left(^{\star}\right)$ Occupations by dispersal of genera from the Oriental region.

Revta bras. Zool. 17 (4): 915 - 940, 2000 




Fig. 3. Distribution of Kramerolidia and Omanolidia (tribe Coelidiini).

The Ethiopian region has a moderately large fauna with most of the genera occupying a broad band in the combined West/East African subregions (mostly tropical), followed by a sharp reduction of taxa exclusive to either of these subregions (Tab. III). Members are rare in the Malagasian subregion where radiation was low, most likely due to isolation of the subregion from mainland Africa. The relationship of the Ethiopian fauna to the Neotropical forms of the tribe, although more distant than the former is to the Oriental fauna, suggests that each group radiated along separate lines after the continents drifted apart, thereby distinguishing the phylogenetic relationships between them. Therefore, we propose that the Neotropical forms are vicariants, established by the separation of the African and South American continents during early Cretaceous.

In the Oriental region, six known genera are dominant in the Indo-Chinese, Indo-Malayan and Indian subregions (Tab. III). One species is widespread. Speciation was particularly profuse for three major genera, Calodia, Lodiana and Taharana. Three small groups (Mahellus Nielson, 1982e, Jenolidia Nielson, 1982e and Stylolidia Nielson, 1986) are widely distributed (Fig. 4). Mahellus has two closely related, disjunct species, one in southern India and one in the Seychelles, the latter of which is now part of the Malagasian subregion in the Ethiopian region but is 


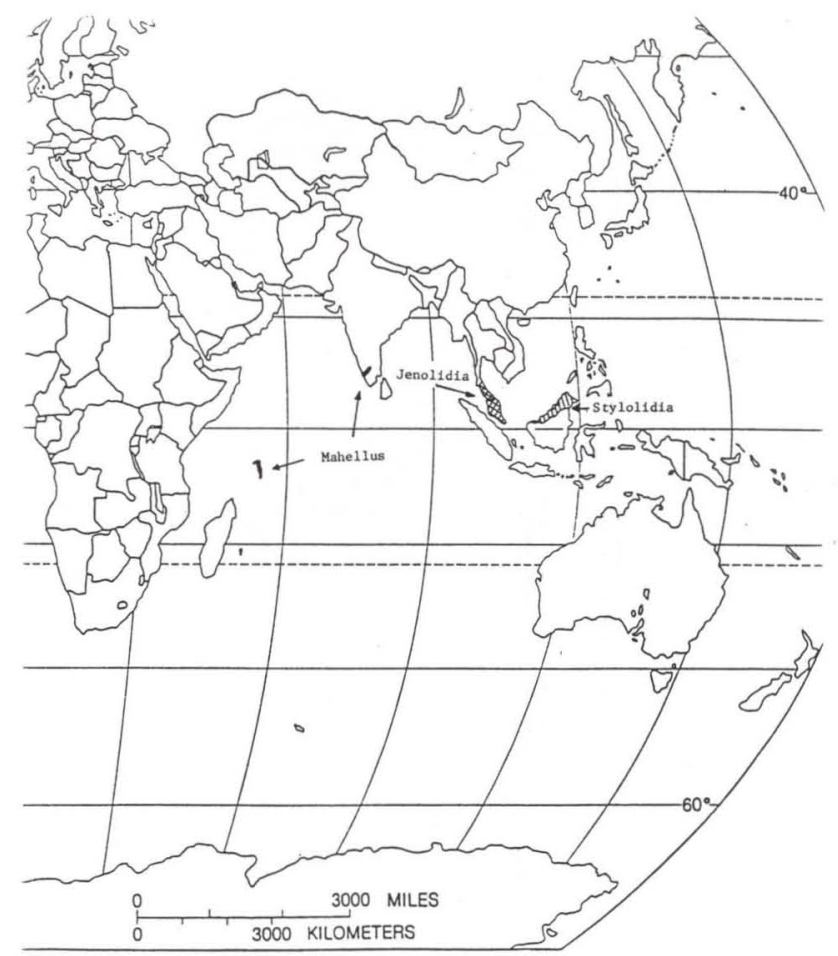

Fig. 4. Distribution of Mahellus, Jenolidia and Stylolidia (tribe Coelidiini).

believed to have had connections with India through the Mascarene plate before the latter drifted southwestwardly (BROWN \& GIBSON 1983). This genus has closer affinities to some West African genera than to the single known Malagasian genus, Limentinus Distant, 1917a, or to other Oriental genera (NIELSON 1983).

Jenolidia and Stylolidia are more closely related to the Oriental genera, Taharana, Calodia, Lodiana, than to the Ethiopian fauna (NIELSON 1983). The last two have radiated profusely in the Indo-Chinese and Indo-Malayan subregions with a few species occupying the eastern Palaearctic region (Fig. 5). One species of Calodia has reached the Austro-Malayan subregion and a few species occur in southern India and Sri Lanka. Another species of Calodia is common in the Indo-Chinese subregion and has been reported from the Seychelles (NIELSON 1982). This example of disjunct distribution at the species level may be an adventitious event.

The Australian and Palaearctic regions are mostly depauperate of members of Coelidiini and their representatives are believed to be the result of dispersal from the Indo-Malayan and Indo-Chinese subregions, respectively (Tab. III).

It is proposed that the pantropical tribe Coelidiini is of Gondwanaland origin. There is no current evidence to otherwise explain the near cosmopolitan distribution and high endemicity across the geographical range of the tribe. The land masses of South America and Africa, which were connected and equatorial during early

Revta bras. Zool. 17 (4): 915 - 940, 2000 




Fig. 5. Distribution of Calodia and Lodiana (tribe Coelidiini)

Jurassic times and are still equatorial today (NORTON \& SCLATER 1979), may have been the pre-drift origin of the tribe. After the continents separated, the groups radiated independently along their own lines. India was attached to southeastern Africa (farther south than previously believed) and is equatorial today (BRIGSS 1989). A major part of the pantropical distribution of the group may have been well in place before the breakup of Gondwanaland about 180 m.y.a. However, the northeastern movement of the Indian subcontinent as a vicariant event for the distribution of certain elements of Coelidiini into the Oriental region and subsequent Indo-Malayan invasion of the Australian realm is plausible. Biotic remnants of the group are evident on the insular tracts between Madagascar and India. Some parts of the Malagasian (Madagascar) fauna are more closely related to the African fauna than to the Oriental group whereas other Malagasian (Seychelles) species are more closely related to the Indian fauna that were associated with the Mascarene plate.

\section{Tribe Teruliini Nielson, 1979}

This large tribe occupies the Neotropical, Nearctic and Ethiopian regions (Fig. 6). In the Neotropical region most of the genera (31) of this tribe occur in and are endemic to the Brazilian subregion and it is possible that the tribe originated 
there (Tab. IV). The remaining genera (13) occur in the northeastern and northwestern zone of the Neotropical region where speciation was particularly evident in the Mexican subregion.

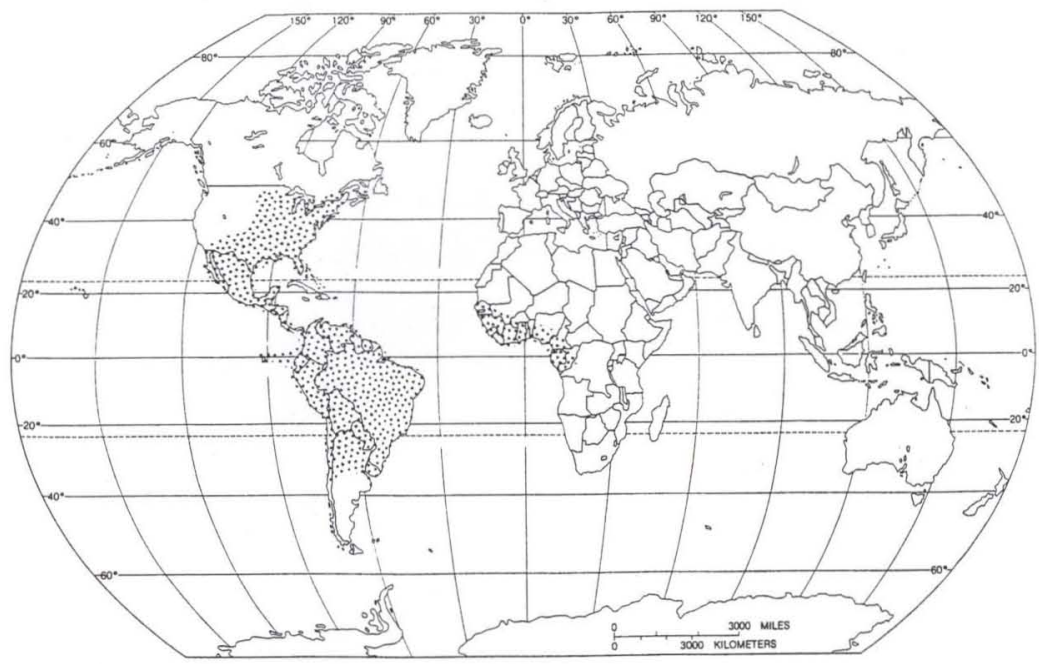

Fig. 6. Distribution of the tribe Teruliini.

Table IV. Distribution of the fauna of the tribe Teruliini in three zoogeographical regions.

\begin{tabular}{|c|c|c|}
\hline Realm and subregion & Number of genera & Number of species \\
\hline \multicolumn{3}{|l|}{ Neotropical } \\
\hline Brazilian & 31 & 220 \\
\hline Brazilian/Mexican & 2 & 3 \\
\hline Brazilian/Mexican/Venezuelian & 3 & 3 \\
\hline Brazilian/Guyana & 1 & 1 \\
\hline Venezuelian/Guyana & 3 & 10 \\
\hline Venezuelian & 2 & 4 \\
\hline Mexican & 4 & 34 \\
\hline Subtotal & 44 & 275 \\
\hline \multicolumn{3}{|l|}{ Nearctic/Neotropical } \\
\hline Allegheny/Mexican & 1 & 2 \\
\hline So.Rocky Mt./Mexican & 1 & 3 \\
\hline Subtotal & 2 & 5 \\
\hline \multicolumn{3}{|l|}{ Neotropical/Ethiopian } \\
\hline Brazilian/West African & 1 & 2 \\
\hline West African & $0^{*}$ & 1 \\
\hline Subotal & 1 & 3 \\
\hline Total & 47 & 283 \\
\hline
\end{tabular}

$\left.{ }^{*}\right)$ Occupation by dispersal from Neotropical region.

Revta bras. Zool. 17 (4): 915 - 940, 2000 
Only two genera have Nearctic/Neotropical distribution. The genus Jikradia Nielson, $1979 \mathrm{~b}$ most likely originated from Neotropical stock with a possible center of origin in the Mexican subregion (Fig. 7). Radiation was rather compressed to the more humid zones, both northward in eastern United States and southward to the Galapagos Islands. Harasupia Nielson, 1979b is restricted to southern Arizona and Baja in the southern Rocky Mountain subregion of the Nearctic region and in the Mexican subregion of the Neotropical realm (Fig. 8). This genus apparently has more tolerance for the dry zones in this region than Jikradia.

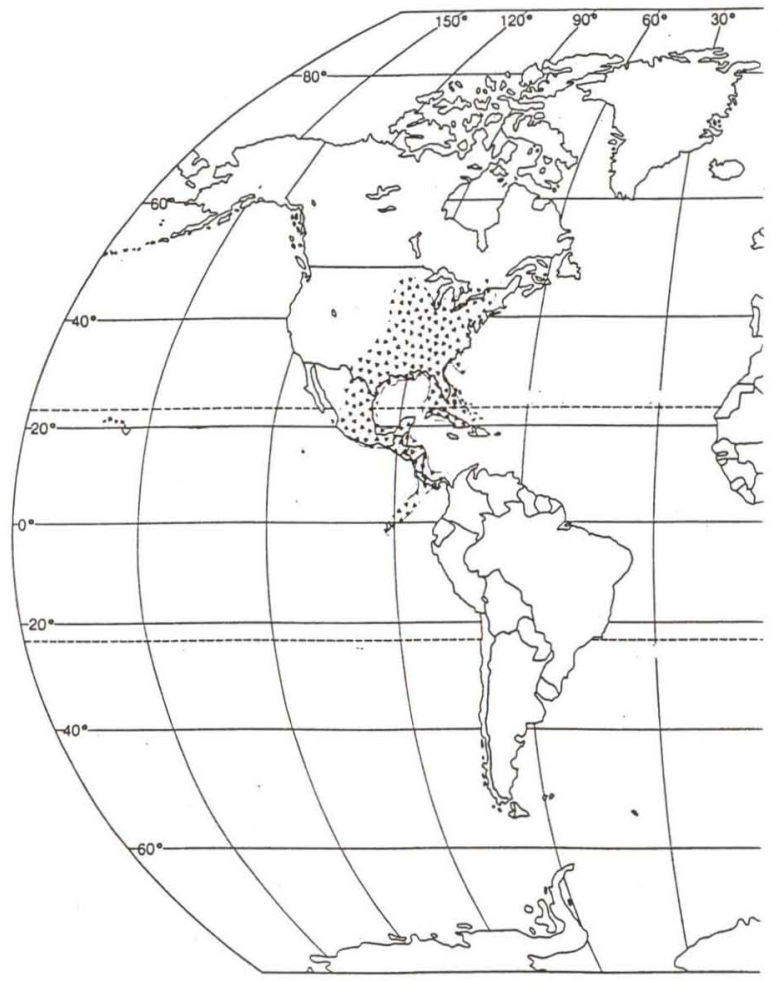

Fig. 7. Distribution of Jikradia (tribe Teruliini).

Elements of both genera appear to have been established in the Mexican subregion from Neotropical stock, then isolated for a period of time when the original land mass of Central America was carried northeastwardly by the Caribbean plate after which radiation occurred north and south when the continents were rejoined during the Miocene. Two subspecies of Jikradia melanota (Spangberg, 1878) occur in the West Indies, where their ancestors are believed to have been carried via the Caribbean plate. In the Neotropical/Ethiopian regions, the disjunct genus, Biadorus Nielson, 1979b, has three very closely related species, two of which are endemic, rare forms ranging from Recife (state of Pernambuco) on the northeast 




Fig. 8. Distribution of Harasupia (tribe Teruliini) and Boliviela (tribe Coelidiini).

coast of Brazil south to the most southern state of Rio Grande Sul and a more common, widespread one, B. africanus, along the central west coast of Africa (Fig. 9). The latter species is the only representative of the tribe outside of the New World and is believed to have been introduced from Brazil to Africa. Trade was especially intense, particularly between Angola and Brazil, during the 17th and 18th centuries when many New World plant species were introduced to Angola (Quartau 1995, personal communication). Although $B$. africanus has not been found in Brazil, its apparent population explosion in Africa and change in the configuration of the aedeagus is not an uncommon biological/morphological phenomenon among adventitious species. Moreover, the dominance of genera of the tribe in the Neotropical region discounts any likelihood of a vicariant event for one species of Biadorus.

The most widespread and largest group of teruliines (over 125 known species) is the genus Docalidia which occupies about 2/3 of South America and the southern part of Central America (Fig. 10). No other New World genus of the subfamily has radiated so successfully as this one. Only one species of the genus, spangleri Nielson, 1979b, is endemic on the Galapagos Islands and apparently is quite abundant (Freytag 1995, personal correspondence). The species is not known on the mainland. 


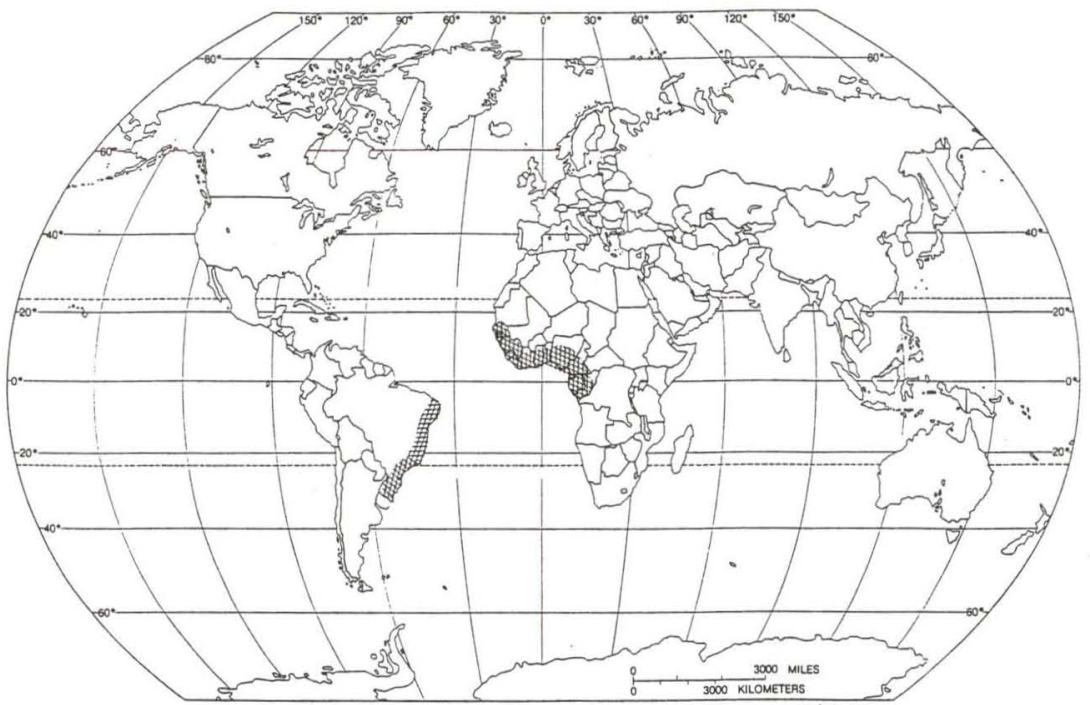

Fig. 9. Distribution of Biadorus (tribe Teruliini).



Fig. 10. Distribution of Docalidia (tribe Teruliini).

Revta bras. Zool. 17 (4): 915 - 940, 2000 
The distributions of the type-genera, Coelidia (Coelidiini) and Terulia Stål, 1862e (Teruliini), are similar and may not be purely coincidental (Fig. 11). The designation of Terulia as the type-genus for the tribe was based on the oldest name available and from the type-species that possessed the principal character separating the two tribes. This character, the clypeal carina, is present and well developed in all Teruliini, but is absent in all Coelidiini except for a few species of Coelidia where it is greatly reduced or incomplete. This character is significant in a biogeographical and phylogenetic sense because the two tribes appear to be related spacially and phenetically. Teruliines are tentatively considered to be a sister-group of Coelidiini based on its endemic Neotropical origin and on the presence of the clypeal carina which is believed to be a derived character.

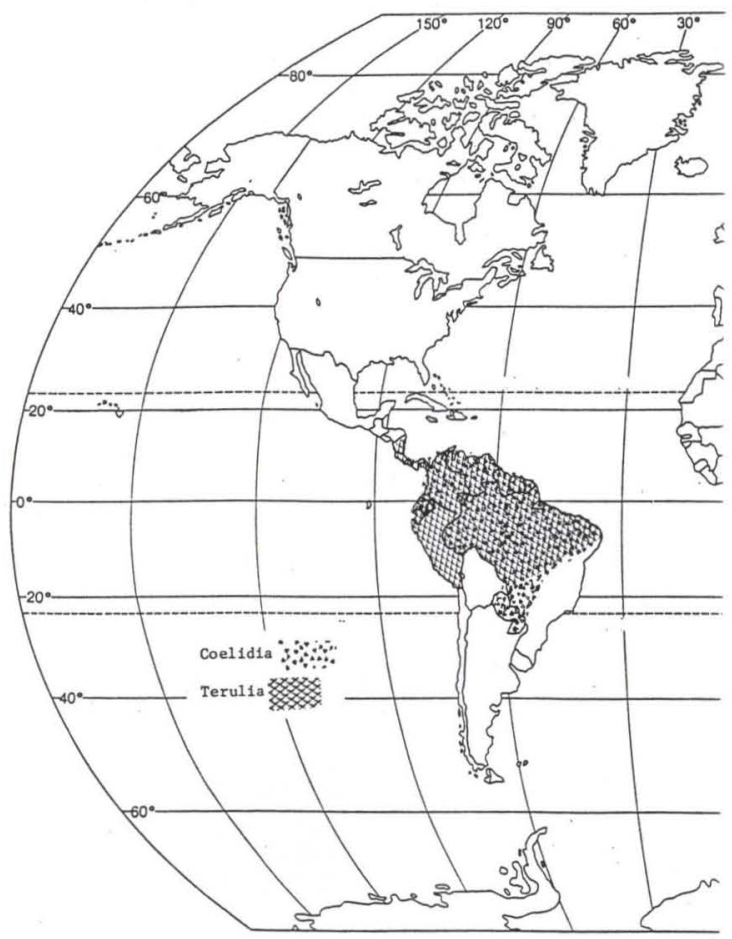

Fig. 11. Distribution of Coelidia (tribe Coelidiini) and Terulia (tribe Teruliini).

\section{Tribe Tinobregmini Oman, 1949}

The tribe's occurrence in the west and northwestern coastal countries of South America, Central America, eastern Mexico and southern United States provides an interesting study of narrow inland biogeography (Fig. 12). The northern and southern extremes of the group's range are exemplified by the genera Tinobregmus Van Duzee, 1894f (Alleghany, southern Rocky Mountain and Mexican subre- 


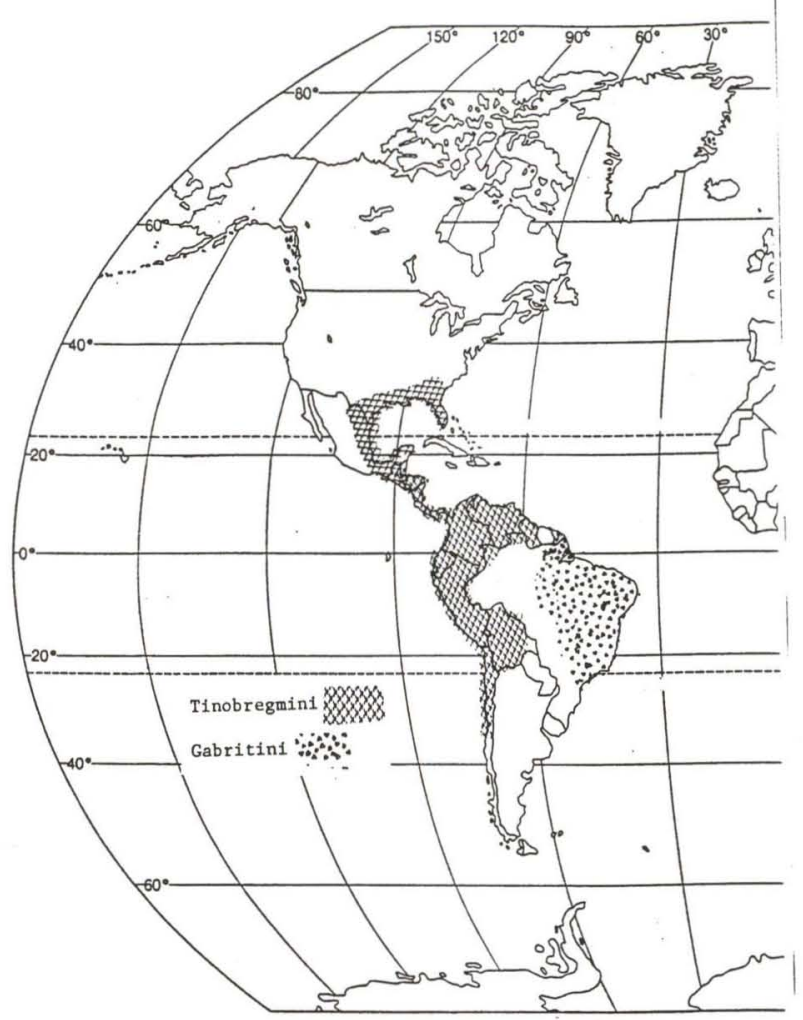

Fig. 12. Distribution of the tribes Tinobregmini and Gabritini.

gions) and Chilelana DeLong, 1969a (Andean subregion), respectively (Tab. V). The habitat of Chilelana is in the dry coastal and low elevation $(600 \mathrm{~m})$ areas of Chile and Bolivia whereas for Tinobregmus it is in the more moist, low eastern coastal areas of Mexico and southern United States. In each case, dispersal appears to be restrained by the development of brachypterous forms. One mainland species of Tinobregmus is rare in Bermuda and none have been reported from the islands of the West Indies. All of the known species in both genera are marked by alary polymorphism. Both sexes may be brachypterous or micropterous and with or without functional wings.

Four major forms of alary polymorphism in leafhoppers have been reported by OMAN (1987). The mechanisms are not well understood because the numerous cases are quite variable in origin. Some morphs may develop in response to environmental cues that signal oncoming seasonal changes that would otherwise discourage development and survival of macropterous species and thus reduce dispersal. Not all forms are caused by ecological factors. In some groups it may be a specialized adaptation for survival in which the wing condition is genetically and permanently fixed in both sexes. However, architectural characteristics of habitats appear to be one of the more important causes of alary polymorphism in leafhoppers (OMAN 1987). 
Table V. Distribution of the fauna of the tribes Tinobregmini and Gabritini in the Nearctic/Neotropical realms.

\begin{tabular}{lcc}
\hline \multicolumn{1}{c}{ Realm and subregion } & Number of genera & Number of species \\
\hline Tinobregmini & & 3 \\
Nearctic/Neotropical & 1 & 3 \\
Alleghany/S. Rocky Mt./Mexican & 1 & 1 \\
\hline Subtotal & 1 & 2 \\
\hline Neotropical & 2 & 1 \\
Mexican/Brazilian & 1 & 4 \\
Brazilian & 4 & 7 \\
Andean & 5 & 4 \\
\hline Subtotal & & 4 \\
\hline Total & 1 & 4 \\
\hline Gabritini & 1 & \\
Neotropical & & \\
Brazilian & & \\
\hline Total & & \\
\hline
\end{tabular}

Tantulidia Nielson, 1979a is represented by a single species which is common in southern Mexico, Central America and rare in Ecuador (NIELSON 1979). No brachypterous forms have been found, and it is one of the groups that does not have pronotal concealment of the base of the tegmina but has other features of the tribe.

Corilidia Nielson, 1982a is represented by one known, endemic macropterous species from Peru (NIELSON 1982). The bases of the tegmina are concealed by the posterior margin of the pronotum. Brachypterous forms are yet unknown.

Stenolidia Nielson, 1986a, represented by one macropterous species, was provisionally placed in the tribe (NIELSON 1986a). It is endemic in Guyana and its representative species lacks two tribal characters (brachyptery and concealed base of the tegmina) but has head and male genital features of the tribe.

The geographical origin of the tribe appears to be Neotropical. Tinobregmus, the only representative of the group in the Nearctic region, likely arose from Neotropical stock and radiated primarily in the southern Nearctic region, possibly after the closing of the Panamanian isthmus during the Miocene (6 m.y.a.).

\section{Tribe Gabritini Nielson, 1983}

This remarkable tribe, characterized by raptorial forelegs, is endemic in Brazil (Fig. 12). Only one genus and four species have been described (NIELSON 1983) (Tab. $\mathrm{V})$. The forelegs appear to mimic a predatory stance, which in all likelihood serves as a survival mechanism from predation. This behaviour is considered an apomorphic trait, along with the presence of a prominent, but incomplete clypeal carina. The tribe's geographical origin may be Brazil, possibly during late Tertiary.

\section{Tribe Youngolidiini Nielson, 1983}

The tribe occupies the Neotropical and Ethiopian regions (Fig. 13). Three genera and 34 species are presently known in the Neotropical region and two genera

Revta bras. Zool. 17 (4): 915 - 940, 2000 


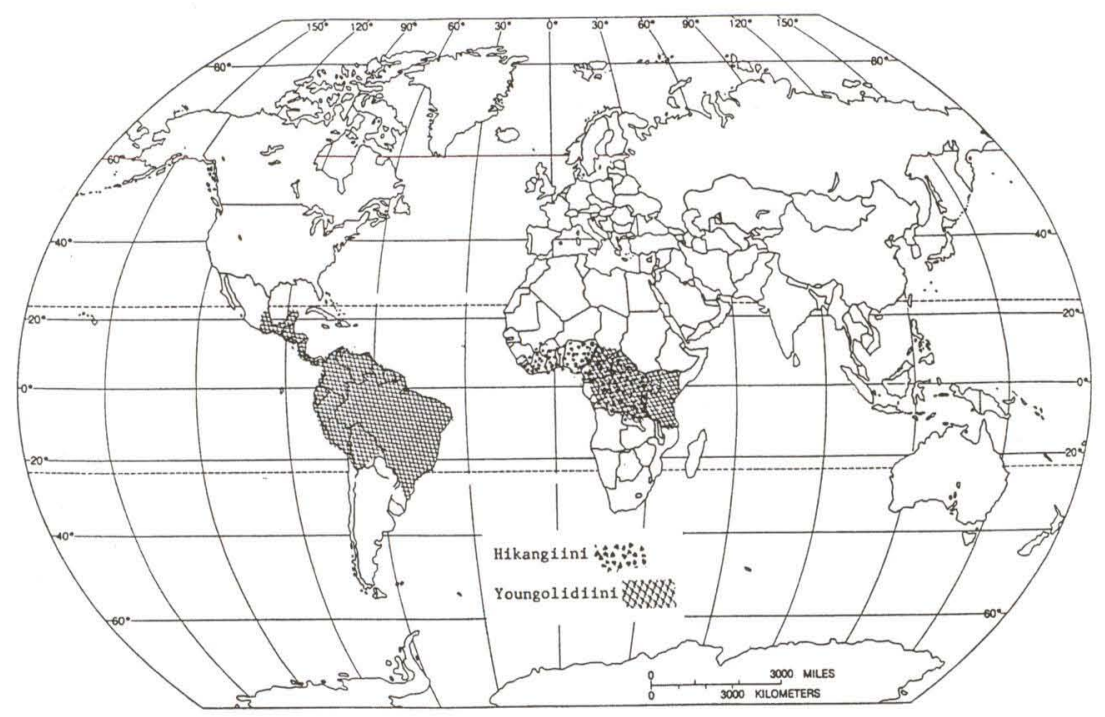

Fig. 13. Distribution of the tribes Hikangiini and Youngolidiini.

and five species are represented in the Ethiopian region (NIELSON 1983) (Tab. VI). The obvious disjunct distribution of Youngolidiini may be explained by the results of a preliminary cladistical analysis which supports two tribes. Further studies are pending. The East African genus Drordana Nielson, 1983 has some genital features similar to the Neotropical genus Pilosana Nielson, 1983. The West African genus Afridonus Nielson, 1983, unfortunately, is known only from females. In the Neotropical region, the two dominant genera are Pilosana and Youngolidia Nielson, 1983 (Fig. 14). Pilosana is much more widespread and a few species have dispersed into the Mexican subregion from possible origin in the Brazilian subregion where radiation was most prevalent. Youngolidia Nielson, 1983 is more restricted to the western tropical countries of South America and is not known in Central America. Rikana Nielson 1983 is represented by two widely separated species, one in Peru and the other in Guyana. The latter record is known only from female specimens. Its placement in the genus was provisional. The New World forms of the tribe are believed to be highly derived but their ancestral origin is problematical.

\section{Tribe Hikangiini Nielson, 1983}

This small tribe is endemic to the Ethiopian region, represented by a few Afrotropical countries (Fig. 13). Only two genera and six species are presently known (NiELSON 1983) (Tab. VI). Hikangia Nielson, 1983 and Boulardus Nielson, 1983 have fairly long heads and a connective-aedeagus fusion which may represent apomorphic traits. Hikangia also possesses a complete median clypeal carina which may represent a homoplasy. The group is neither closely related to the Ethiopian Youngolidiini nor to the Neotropical or Oriental fauna of Coelidiini and may have radiated slowly along a separate line from ancestral stock of the tribe Coelidiini. 




Fig. 14. Distribution of Youngolidia and Pilosana (tribe Youngolidiini).

Table VI. Distribution of the fauna of the tribes Youngolidiini and Hikangiini in two zoogeographical regions.

\begin{tabular}{lcr}
\hline \multicolumn{1}{c}{ Realm and subregion } & Number of genera & Number of species \\
\hline Youngolidiini & 2 & 33 \\
Neotropical & 1 & 1 \\
Brazilian & 3 & 34 \\
Brazilian/Mexican & 2 & 5 \\
\hline Subtotal & \multicolumn{2}{c}{39} \\
\hline Ethiopian & 5 & \\
West/East African & \multicolumn{2}{c}{6} \\
\hline Total & 2 & 6 \\
\hline Hikangiini & 2 & 6 \\
Ethiopian & & \\
West African & 2 & \\
\hline Total & & \\
\hline
\end{tabular}

\section{Tribe Sandersellini DeLong, 1945}

This unique, monobasic tribe presently ranges from Bolivia north to the Panamanian-Costa Rican border, thus occupying the western Brazilian and Mexican subregions (Fig. 15). Only one genus and nine species are presently known (Tab. VII). 




Fig. 15. Distribution of the tribe Sandersellini.

Table VII. Distribution of the fauna of the tribe Sandersellini in the Neotropical region.

\begin{tabular}{|c|c|c|}
\hline Subregion & Number of genera & Number of species \\
\hline Brazilian & 1 & 8 \\
\hline Mexican & $0^{*}$ & 1 \\
\hline Total & 1 & 9 \\
\hline
\end{tabular}

(*) Occupation by dispersal from Brazilian subregion.

The presence of the paired lateral pronotal carinae is considered a derived trait and is not possessed by any other group in the family Cicadellidae. The genus is endemic to the Neotropical region. Its origin appears to be in northern South America and dispersed northward during the Miocene after the continents were joined.

\section{Tribe Thagriini Distant, 1908}

Thagriines are widely distributed in the Oriental region with considerable extension into the Australian and eastern Palaearctic regions (Fig. 16). They are not known in Australia. Only two genera are recognized, Thagria with 182 species and Tahara Nielson, 1977a with two species (Tab. VIII). 


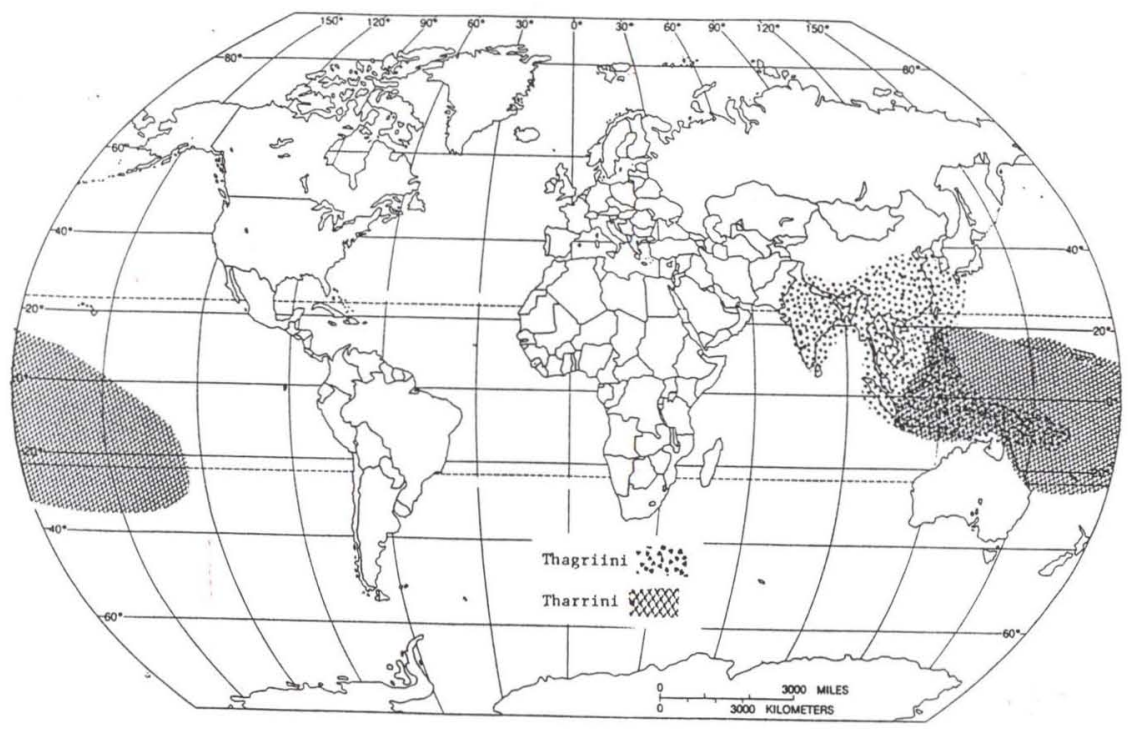

Fig. 16. Distribution of the tribes Thagriini and Tharrini.

Speciation in Thagria has been prodigious in the Indo-Chinese, Indo-Malayan and Austro-Malayan subregions. Tahara is known only from New Guinea and has some characters shared by Thagria and Tharra of the tribe Tharrini and it may represent the phylogenetic link between the two tribes.

It is noteworthy that thagriines have a unique male genital apparatus consisting of a narrow aedeagus lying dorsad of and articulated with a large, often asymmetrical, ventral paraphysis. Such presence is considered derived from the aedeagal type that lacks a paraphysis which is a common feature among other tribes. The plates are segmented subbasally, the presence of which are also considered a derived trait. The ancestral origin of thagriines is somewhat problematical. Its geographical origin is clearly Oriental in the Indo-Malayan region.

\section{Tribe Tharrini Nielson, 1975}

This tribe is well distributed in the Australian region with intrusion into the Oriental region (Indo-Malayan) and to a much lesser extent into Australia proper. Three species are presently known in northeastern part of the region hand they may be either dispersants or introductions (Fig. 16). Speciation in Tharra has been especially prolific in the Austro-Malayan and Polynesian subregions. Three genera of Tharra are presently known. Two genera, Neotharra and Haranthus Nielson, 
1975a are currently monotypic and are endemic to New Guinea. Tharra is widespread and has 97 known species (Tab. VIII).

Table VIII. Distribution of the fauna of the tribes Thagriini and Tharrini in three zoogeographical regions.

\begin{tabular}{|c|c|c|}
\hline Realm and subregion & Number of genera & Number of species \\
\hline \multicolumn{3}{|l|}{ Thagriini } \\
\hline \multicolumn{3}{|l|}{ Oriental } \\
\hline Indo-Chinese & $0^{*}$ & 66 \\
\hline Indo-Malayan & 1 & 43 \\
\hline Indian & $0^{*}$ & 14 \\
\hline Subtotal & 1 & 123 \\
\hline \multicolumn{3}{|l|}{ Australian } \\
\hline Austro-Malayan & 1 & 54 \\
\hline Polynesian & $0^{*}$ & 2 \\
\hline Subtotal & 1 & 56 \\
\hline \multicolumn{3}{|l|}{ Palaearctic } \\
\hline Manchurian & $0^{*}$ & 3 \\
\hline Indo-Chinese/Indo-Malayan & $0^{*}$ & 2 \\
\hline Subotal & 0 & 5 \\
\hline Total & 2 & 184 \\
\hline \multicolumn{3}{|l|}{ Tharrini } \\
\hline Oriental & $0^{*}$ & 10 \\
\hline \multicolumn{3}{|l|}{ Australian } \\
\hline Austro-Malayan & 3 & 52 \\
\hline Polynesian & $0^{*}$ & 40 \\
\hline Australia Proper & $0^{*}$ & 3 \\
\hline Subotal & 3 & 89 \\
\hline Total & 3 & 99 \\
\hline
\end{tabular}

* Occupation by dispersal from Austro-Malayan subregion.

Many species of Tharra are endemic to New Caledonia, an island whose geological origin is problematical (BROWN \& GIBSON 1983). It has connection to either eastern New Guinea or to New Zealand but its association with the latter region carries a number of geological uncertainties. New Guinea has a rich Tharra fauna and, in the absence of this group in New Zealand, suggests that New Caledonia had geologic ties with New Guinea to account for their close faunistic relationship.

The geographical origin of the tribe appears to be the Australian region with its center in New Guinea (if Tahara represents the tribal link) from which radiation proliferated into the Polynesian subregion after the islands formed during the Cretaceous period (BROWN \& GIBSON 1983). Members of the tribe have male genitalia characterized by a bipendulate aedeagus, consisting of a dorsal paraphysis and ventral tubular aedeagus which are fused basally, a condition that is reversed from the Thagriini. The plates are also segmented subbasally. The presence of these features are considered derived and are mentioned here because they may have developed in concert with the geographical development of the Polynesian subregion. 


\title{
DISCUSSION
}

The high incidence of endemism and revealing distributional patterns are offered as initial -vidence for proposing Gondwanaland and late Jurassic/early Cretaceous as the possible ancestral origin of the widespread subfamily Coelidiinae, notwithstanding the importance of phylogenetic analysis which has yet to be done for the group. This proposal is not without precedence as other cosmopolitan subfamilies (viz. Deltocephalinae, Typhlocybinae) show similar evidence to explain their current distributions and historical origins (NIELSON \& KNIGHT 2000).

The pantropical tribe Coelidiini with its widespread endemic genera may be the precursorial stock from which other tribes (Teruliini, Tinobregmini, SanderseIlini, Hikangiini, Thagriini) descended, at least from those members whose distributions are confined either in the New World or Old World hemispheres. Late tribal radiation appears to include Gabritini (from Teruliini) in the New World and Tharrini (from Thagriini) in the Old World. The origin of Youngolidiini (Old and New World) is more problematical.

\begin{abstract}
ACKNOWLEDGMENTS. The authors express their appreciation to two anonymous reviewers and the following reviewers who offered substantive suggestions for improving the content and textual expressions in this paper: Raymond Gill, California Department of Food \& Agriculture, Sacramento, USA; Gabriel Mejdalani, Departamento de Entomologia, Museu Nacional, Universidade Federal do Rio de Janeiro, Rio de Janeiro, Brasil and J.A. Quartau, Departamento de Zoologia e Antropologia, Universidade de Lisboa, Portugal. We thank Dr. Aiping Liang, Institute of Zoology, Academia Sinica, Beijing, China for the preliminary character analysis of the tribes that indicated division of Youngolidiini into two separate tribes.
\end{abstract}

\section{REFERENCES}

All leafhopper references cited before 1956 are found in:

Metcalf, Z. P. 1964. General Catalogue of the Homoptera. Fascicle VI. Cicadelloidea. Bibliography of the Cicadelloidea (Homoptera:Auchenorrhyncha). U.S. Department of Agriculture, Agricultural Research Service. Washington, D. C., 349 pp.

Those cited between 1956-1985 are found in:

OMAN, P. W., W. J. KNiGht \& M.W. NiELSON. 1990. Leafhoppers (Cicadellidae): A bibliography, generic check-list and index to the World literature 1956-1985. C.A.B. International Institute of Entomology. Wallingford, Oxon, 368p.

BRIGGS, J.C. 1989. The historic biogeography of India: Isolation or contact? Syst. Zool. 38 (4): 322-332.

BRown, J.H. \& A.C. GiBSon. 1983. Biogeography. St. Louis, The C.V. Mosby Company, 654p.

CONEY, P.J. 1982. Plate tectonic constraints on biogeographic connections between North and South America. Ann. Missouri Bot. Gard. 69 (3): 432-443.

DARLINGTON, P.J. 1938. The origin of the fauna of the Greater Antilles, with discussion of dispersal of animals over water and through the air. Quar. Rev. Biol. 13: 274-300.

Godoy, C. \& M.W. Nielson. 1998. A review of the leafhopper genus Jikradia with descriptions of four new species (Homoptera:Cicadellidae). Rev. Biol. Trop. 46 (3): 739-748.

GooD, R. 1974. The geography of flowering plants. New York, John Wiley \& Sons Inc., $4^{\text {th }}$ ed., 557p.

Kellogi, J.N. \& V. Vega. 1995. Tectonic development of Panama, Costa Rica, and the Colombian Andes: Constraints from global positioning system geodetic studies and gravity, p. 75-87. In: P. MANN (Ed.). Geologic and tectonic development of the Caribbean plate boundary in southern

Revta bras. Zool. 17 (4): 915 - 940, 2000 
Central America. Boulder, CO, Geological Society of America Special Paper 295.

LI, Z. 1988. Three new species of Fanjingshan mountainous leafhoppers from Guizhou, China (p. 87-91). Special Studies of the Entomological Expedition of Fanjingshan Mountains. Guizhou Science, $155 \mathrm{p}$.

1989. Five new species of Coelidiinae from Guizhou province (Homoptera:Cicadellidae). Jour. Guizhou Agri. College 1: 1-5.

. 1991. Four new species of the genus Taharana from China. Acta Zool. Sinica 16 (34): 354-359.

- 1993. A taxonomic study of Chinese genus Thagria (Homoptera: Coelidiinae). Jour. Guizhou Agri. College 12: 29-33.

LI, Z. \& L. WANG. 1989. Three new species of Lodiana from Guizhou province, China. Jour. Guizhou Agri. College 2: 1-3.

1991. Agriculture and Forestry insect fauna of Guizhou. Guizhou, Science and Technology Printing House, 304p.

MACARTHUR, R.H. \& E.O. WiLSON. 1967. The theory of island biogeography. Monographs in population biology no. 1. Princeton, Princeton University Press, 203p.

Nielson, M.W. 1986a. New genus and species of leafhopper in the tribe Tinobregmini (Homoptera, Cicadellidae, Coelidiinae). Great Basin Nat. 46 (1): 134-136.

. 1986b. New Oriental genus of leafhoppers in the tribe Coelidiini with descriptions of new species (Homoptera: Cicadellidae: Coelidiinae). Great Basin Nat. 46 (1): 137-139.

-1986c. New thagriine leafhoppers from the Oriental region, with a key to 30 species (Homoptera: Cicadellidae: Coelidiinae). Great Basin Nat. 46 (2): 321-328.

-1986d. Genus Paralidia with descriptions of new species (Homoptera:Cicadellidae:Coelidinae). Great Basin Nat. 46 (2): 329-335.

-1986e. New South American leafhoppers in the genus Docalidia, with a key to 37 species (Cicadellidae: Coelidiinae: Teruliini). Great Basin Nat. 46 (4): 749-762.

.1988a. New genera and new species of Neotropical Coelidiini (Homoptera:Cicadellidae:Coelidiinae). Great Basin Nat. 48 (2): 232-249.

.1989a. On the genus Paracarinolidia (Cicadellidae: Coelidiinae: Teruliini). Great Basin Nat. 49 (1): 92-95.

-1989b. Two new genera and two new species of teruliine leafhoppers (Homoptera: CicadeIlidae: Coelidiinae). Great Basin Nat. 49 (1): 96-99.

- 1989c. New species of Harasupia with a revised key to the species (Homoptera:Cicadellidae:Coelidiinae). Great Basin Nat. 49 (2): 233-240.

- 1989d. Additional new species of teruliine leafhoppers with key to species (Cicadellidae: Coelidiinae: Teruliini). Great Basin Nat. 49 (3): 398-403.

-1990a. New species of Docalidia from the Neotropical region (Homoptera:Cicadellidae:Coelidiinae). Entomol. Scand. 21 (2): 225-240.

-1990b. New Oriental leafhoppers in the tribe Coelidiini with a revised key to the species (Homoptera: Cicadellidae: Coelidiinae). Entomol. Scand. 21 (4): 445-475.

. 1991a. Afrotropical leafhoppers in the tribe Coelidiini (Homoptera: Cicadellidae: Coelidiinae). Part 1. New taxa with a revised key to species. Jour. African Zool. 105 (5): 393-428.

.1992a. Afrotropical leafhoppers in the tribe Coelidiini (Homoptera: Cicadellidae: Coelidiinae). Part 2. Additional new taxa with taxonomic notes and a revised key to genera and species. Jour. African Zool. 106 (3): 211-242.

1992b. New species of leafhoppers in the genera Thagria (Thagriini) and Tharra (Tharrini) from Indonesia (Homoptera: Cicadellidae: Coelidiinae). Entomol. News 103 (3): 65-71.

1992c. New species of Neotropical leafhoppers in the tribe Coelidiini (Homoptera: Cicadellidae: Coelidiinae) with a revised key to some species. Entomol. News 103 (4): 93-102.

.1992d. New species of Neotropical leafhoppers in the tribe Youngolidiini with a revised key to species (Homoptera:Cicadellidae:Coelidinae). Entomol. Scand. 23 (3): 289-296. 
1992e. New species of Neotropical leafhoppers in the tribe Teruliini with a revised key to some species (Homoptera: Cicadellidae: Coelidiinae). Entomol. Scand. 23 (3): 297-305.

- 1996a. Two new Neotropical genera and new species of Docalidia in the tribe Teruliini (Cicadellidae:Coelidiinae). Trans. Amer. Entomol. Soc. 122 (2/3): 135-145.

. 1996b. Two new genera and some new species of Neotropical and Oriental leafhopers in the tribe Coelidiini (Cicadellidae:Coelidiini). Trans. Amer. Entomol. Soc. 122 (2/3): 147-160.

. 1996c. A new species of Pilosana from Costa Rica (Homoptera: Cicadellidae). Entomol. News 107 (5): 327-328.

Nielson, M.W. \& W.J. KNIGHT. 2000. Distributional patterns and possible origins of leafhoppers (Homoptera, Cicadellidae). Revta Bras. Zool. 17 (1): 81-156.

NORTON, I.O. \& J.A. SCLATER. 1979. A model for the evolution of the Indian ocean and the breakup of Gondwanaland. Jour. Geophy. Res. 84: 6803-6830.

OMAN, P.W. 1987. Alary polymorphism in the Cicadellidae and its ecological implications, p. 55-63. In: M.R. WILSON; \& L.R. NAULT (Eds). Proc. $2^{\text {nd }}$ Internat. Workshop on leafhoppers and planthoppers of economic importance. Provo, Brigham Young University, 28 Jul-1 Aug., CAB International Institute of Entomology, 368p.

OMAN, P.W.; W.J. KNIGHT \& M.W. NiEI.SON. 1990. Leafhoppers (Cicadellidae): A bibliography, generic check-list and index to the World literature, 1956-1985. Wallingford, C.A.B. International Institute of Entomology, 368p.

THeron, J.G. 1986a. New genera and species of southern African Coelidiinae (Homoptera: Cicadellidae), with description of the new tribe Equeefini. Phytophyl. 18: 153-163.

. 1986b. Leafhoppers (Homoptera: Cicadellidae) associated with the renosterbos, Elytropappus rhinocerotis Less. III. The genera Equeefa Distant and Chlorita Fieber. Jour. Entomol. Soc. South Africa 49 (1): 95-105.

THORNE, R.F. 1973. Floristic relationships between tropical Africa and tropical America, p. 27-47. In: B.J. Meggers; E.S. Ayensu \& W.D. DuCKworTh (Eds). Tropical forest ecosystems in Africa and South America: a comparative review. Washington, D.C., Smithsonian Institute Press.

ShCilerbakov, D.E. 1992. The earliest leafhoppers (Hemiptera: Karajassidae, n.fam.) from Jurassic of Karatau. Neues Jahrbuch Geol. Paleontol Momatsh. 1: 39-51.

WALLACE, A.R. 1876. The geographical distribution of animals. London, Macmillan, Vol. 2.

ZHANG, Y. 1990. A taxonomic study of Chinese Cicadellidae (Homoptera). Tianze Eldonejo, Yangling, Shaanxi, China, 218p.

-1994. A taxonomic study of Chinese Coelidiinae (Homoptera: Cicadellidae. Henan Science and Technology Press, 151p.

ZiIANG, Y. \& A. YANG. 1994. Two new species of the genus Thagria Melichar (Homoptera: Cicadellidae). Entomol.Res., Shaanxi Normal University Press, Xian, China, p. 1-4.

Zhang, Y. \& Y. Zilang. 1994. Two new species and one new record of the genus Taharana Nielson (Homoptera:Cicadellidae). Entomotaxomia 16 (2): 95-98.

Recebido em 28.X.1999; aceito em 02.X.2000 